\title{
Ar-Ge Yatırımlarının Finansal Performans Üzerindeki Etkisi Ve Bist Teknoloji Endeksi Firmalarının Etkinliklerinin Değerlendirilmesi
}

\author{
Levent ÇITAK ${ }^{*}$
} Yüksel İLTAŞ**

\section{ÖZET}

Bu çalışmada Borsa İstanbul Teknoloji Endeksi'nde (XUTEK) yer alan firmaların araştırmageliştirme yatırımlarının etkinlikleri analiz edilmektedir. Firmaların araştırma-gelişstirme yatırımları bakımından birbirleri ile göreli etkinlikleri 2013, 2014 ve 2015 yıllarına ait veriler kullanılarak üç etkinlik türü üzerinden analiz edilmektedir. Ar-Ge yoğunluğu ve Ar-Ge/Aktifler değişkenlerinin iki girdi, aktif karlılık oranı ve piyasa değeri/defter değeri oranı değiş̧kenlerinin iki çıktılar olduğu CCR (Charnes, Cooper ve Rhodes (1978)) ve BCC ((Banker, Charnes ve Cooper (1984)), veri zarflama modelleri kullanılmıştır. Çalı̧̧manın bulguları firmaların saf teknik etkinlik düzeylerinin göreli olarak yüksek olduğunu ve 2015 'te beş firmanın tam saf teknik etkinliğe sahip oldukların göstermektedir. Dolayısıyla, firmaların toplam teknik etkinliklerinin artırmak için genel olarak ölçek etkinliklerini arttırmaları gerektiği söylenebilir.

Anahtar Kelimeler: Ar-Ge Harcamalarl, Finansal Performans, Veri Zarflama Analizi, Etkinlik. JEL Sinıflandırması: L20, L25, O30.

The Effect Of R\&D Investment on Financial Performace And Evaluation Of The Efficiencies Of Firms Included In Bist Technology Index

\section{ABSTRACT}

In this study analyzes efficiencies of research and development ( $\& D)$ investments of firms included in Borsa İstanbul Technology Index (XUTEK). Based on 2013, 2014 and 2015 data, the relative efficiencies of firm's, in term of their research and development investments, are analyzed on the basis of three efficiency types. CCR (Charnes, Cooper ve Rhodes (1978)), as well as BCC ((Banker, Charnes ve Cooper (1984)) data envelopment models are used, where R\&D intensity and $R \& D / T o t a l$ Assets are two input and return on assets ratio and market-to-book value ratio are the two outputs. The findings of the study show that the pure technical efficiency levels of the companies are relatively high and that in 2015 the five firms have full pure technical efficiency. Therefore, it can be said that companies need to increase their scale activities in general in order to increase their total technical activities.

Keywords: R\&D Investment, Financial Performance, Data Envelopment Analysis, Efficiency.

Jel Classification: L20, L25, O30.

\footnotetext{
* Prof. Dr. Levent Çıtak, Erciyes Üniversitesi, İktisadi ve İdari Bilimler Fakültesi, lcitak@erciyes.edu.tr.

** Yrd. Doç. Dr. Yüksel İltaş, Ahi Evran Üniversitesi, İktisadi ve İdari Bilimler Fakültesi, yiltas@ahievran.edu.tr.
} 


\section{GİRiş}

Küresel ortamda rekabetin daha yoğun ve keskin bir hal almasıyla birlikte yeni ekonomik anlayış bilim ve teknoloji temeline dayanmıştır. Bu bağlamda küreselleşen dünyada sürdürülebilir ekonomik büyüme, ne kadar yenilik üretildiği ile ilişkilendirilmektedir (Ünal ve Seçilmiş, 2013:12). İşletmelerin rekabet üstünlüğü sağlayarak satışlarını artırabilmeleri ve kârlarını maksimize edebilmeleri için işletme stratejilerinde farklılaşmaya, yeniliğe ve yenileşmeye yönelmeleri gerekmektedir.

İşletmeler açısından Araştırma-Geliştirme(Ar-Ge) yatırımları, yeni bir ürün üretmek ve bunu ticari bir kimliğe bürüyerek işletme satışlarını ve dolayısıyla kârlılığını artırmak, özellikle uzun vadede işletmenin varlığını sürdürebilmesi için önem arz etmektedir (Işsı vd. 2016:28). Ar-Ge giderleri yeni bir ürün veya ileri teknoloji geliştirmek için yapılan araştırma giderleri ile araştırma bulgularının yeni ürünler, varlıklar, üretim yöntemleri, sistemler veya hizmetler için projeye dönüştürülmesinde katlanılan geliştirme giderlerinden oluşur (Öğredik, 2005:1).

İşletmelerin, faaliyetlerinde devamlılığı sağlayabilmek ve piyasada tutunabilmek için mevcut bilgiyi ve teknolojiyi geliştirmesi, yeni fikirler ve teknikler üretmesi, tüketici ihtiyaçlarını en iyi şekilde karşılaması, gelişmeyi sürekli hale getirmesi ve rakip işletmelere göre farklılığı daha hızlı yakalayabilmesi gerekmektedir (Ünal ve Seçilmiş, 2014: 203). ArGe harcamaları firmanın teknoloji yeteneğini tanımlamakta kullanılan değişkenlerden birisi olup, işlemeler gücünü yürüttüğü Ar-Ge faaliyetlerinden almaktadır. Sanayi gelişimi, uluslararası ticaretin artması ve artan üretim kapasiteleri gibi etkenler global arenada rekabetin artmasına neden olmakta ve işletmeler girdikleri pazarda kendi farklılıklarını ortaya koymak için Ar-Ge faaliyetlerine yönelmektedirler. Bu bağlamda işletmelerin sürekli ve sistemli olarak yaptığg Ar-Ge faaliyetleri, genel olarak bir sonuç değil, bir süreçtir.

İşletmeler için Ar-Ge faaliyetlerinin temel taşı yeniliktir. Yani yeni ürünler geliştirmek veya keşfetmektir. Ar-Ge'nin gün geçtikçe önem kazandığ 1 günümüz dünyasında Ar-Ge faaliyetlerini bir kaldıraç olarak kullanabilen işletmeler üretimlerini ve beraberinde gelirlerini artırabilir. Rekabetçi güç elde etmek isteyen işletmeler hem yenilikçi hem de verimli olmak durumundadırlar. $\mathrm{Bu}$ nedenle işletmeler bütçelerinden daha çok payı Ar-Ge ve yenilik harcamalarına ayırmaları gerekmektedir.

Çalışmada, Giriş bölümünü takiben, konuya ilişkin Literatür Incelemesine yer verilmektedir. Araştırma modeli ve kullanılan girdi ile çıktılar bölümünde veri zarflama analizi tanımlanarak, kullanılan veri zarflama modelleri tanıtılmakta ve çalışmada yer verilen girdi ve çıktılar açıklanmaktadır. Sonrasında ise model sonuçları ve ampirik bulgular sunulmaktadır. Çalışma, Sonuç ve Öneriler bölümü ile sonlandırılmaktadır. 


\section{LITERATÜR İNCELEMESİ}

Literatür incelemesinde Ar-Ge giderleri ile satış hasılatı arasındaki ilişkiye yönelik birçok çalışmaya rastlanmıştır. Konuya ilişkin yapılan yabancı ve yerli çalışmaların özet bilgileri aşağıdaki tabloda topluca gösterilmektedir.

Tablo 1. Literatür Taraması Özet Sonuçlar

\begin{tabular}{|c|c|c|c|c|}
\hline Yazar(lar) & Veri Seti & Metodoloji & $\begin{array}{l}\text { Kullanılan } \\
\text { Değişkenler }\end{array}$ & Bulgular \\
\hline $\begin{array}{l}\text { Scherer } \\
\text { (1965) }\end{array}$ & $\begin{array}{l}\text { En Büyük } 500 \\
\text { ABD Sanayi } \\
\text { Şirketlerini } \\
\text { Belirleyen } \\
\text { Fortune } \\
\text { Listesindeki } \\
\text { 448 Firma, } \\
\text { 1955-1959 }\end{array}$ & Regresyon & $\begin{array}{l}\text { Patentli } \\
\text { İcatların Sayısı, } \\
\text { Satış Hasılatı, } \\
\text { Firma Kârlılığı } \\
\text { Büyümesi. }\end{array}$ & $\begin{array}{l}\text { Ar-Ge faaliyetleri şirketin } \\
\text { satışlarını arttırmakta ve } \\
\text { böylelikle şirket kârlılığına } \\
\text { dolaylı yoldan ratkı } \\
\text { sağlanmaktadır. Ayrıca patent } \\
\text { çıarma ile ölçülen şirket kâr } \\
\text { büyümesi icat edilen } \\
\text { ürünlerle doğrudan ilişkilidir. }\end{array}$ \\
\hline $\begin{array}{l}\text { Mowery } \\
\text { (1983) }\end{array}$ & $\begin{array}{l}200 \text { Amerikan } \\
\text { Firmas1, } \\
\text { 1921-1946 }\end{array}$ & Regresyon & $\begin{array}{l}\text { Ar-Ge } \\
\text { Personeli, } \\
\text { Firma Boyutu. }\end{array}$ & $\begin{array}{l}\text { 1933-1946 yılları arasında } \\
\text { Ar-Ge personeli çalıştırmak } \\
\text { firma boyutunu pozitif } \\
\text { etkilemiştir. Ayrıca çalışmada } \\
\text { Ar-Ge harcamaları hem } \\
\text { büyük hem de küçük ölçekli } \\
\text { firmaların boyutunu pozitif } \\
\text { yönde etkilemiştir. }\end{array}$ \\
\hline $\begin{array}{l}\text { Geroski } \\
\text { ve } \\
\text { Toker } \\
\text { (1996) }\end{array}$ & $\begin{array}{l}\text { İngiltere İmalat } \\
\text { Firmas1, } \\
\text { 1979-1986. }\end{array}$ & Regresyon & $\begin{array}{l}\text { Satışların } \\
\text { Logaritması, } \\
\text { İhracat ve } \\
\text { İthalat oranı, } \\
\text { İcat Ürün } \\
\text { Sayısı, Toplam } \\
\text { Reklamlar, } \\
\text { Endüstrinin } \\
\text { Satış } \\
\text { Büyümesi, } \\
\end{array}$ & $\begin{array}{l}\text { Ar-Ge faaliyetleri ile } \\
\text { satışların büyümesi arasında } \\
\text { güçlü ve pozitif yönlü bir } \\
\text { ilişki tespit edilmiştir. }\end{array}$ \\
\hline $\begin{array}{l}\text { Roper } \\
(1997)\end{array}$ & $\begin{array}{l}\text { Küçük Ölçekli } \\
\text { Almanya, } \\
\text { İngiltere ve } \\
\text { İrlanda } \\
\text { Firmalar1, } \\
\text { 1991-1993. }\end{array}$ & $\begin{array}{l}\text { Anket, } \\
\text { Araştırma } \\
\text { Raporu. }\end{array}$ & $\begin{array}{l}\text { İnovatif Ürün } \\
\text { Geliştirme, } \\
\text { Firma Satış } \\
\text { Büyümesi. }\end{array}$ & $\begin{array}{l}\text { Almanya, İngiltere ve İrlanda } \\
\text { firmaları için satışların } \\
\text { artırılmasında inovatif ürün } \\
\text { geliştirmenin katkısı olduğu } \\
\text { sonucuna ulaşılmıştır. } \\
\text { Almanya için satış büyümesi } \\
\text { ürün yeniliği stratejisi ile } \\
\text { sağlanmıştır. Bu durum } \\
\text { üretkenliği artırmış fakat } \\
\text { istihdamı azaltmıştır. } \\
\text { İngiltere ve İrlanda firmaları, } \\
\text { üretkenliği ve istihdamı } \\
\text { birlikte düşünerek inovatif } \\
\text { ürün geliştirmede daha } \\
\text { dengeli davranmışlardır. } \\
\text { Alman firmaları İngiltere ve } \\
\text { İrlanda firmalarına göre daha } \\
\text { az pazar odakl, daha az riskli } \\
\text { ve daha örgütlenmiş } \\
\text { yaklaşımı benimsemişlerdir. }\end{array}$ \\
\hline
\end{tabular}




\begin{tabular}{|c|c|c|c|c|}
\hline $\begin{array}{l}\text { Freel } \\
(2000)\end{array}$ & $\begin{array}{l}228 \text { Küçük } \\
\text { Ölçekli İngiliz } \\
\text { Firması, }\end{array}$ & $\begin{array}{l}\text { Non- } \\
\text { Parametrik } \\
\text { Test. }\end{array}$ & $\begin{array}{l}\text { Firma } \\
\text { Büyümesi, } \\
\text { Satışlar, } \\
\text { İstihdam, } \\
\text { Karlılık, } \\
\text { Verimlilik, } \\
\text { İhracat ve } \\
\text { İhracat } \\
\text { Yoğunluğu. }\end{array}$ & $\begin{array}{l}\text { Çalışmada elde edilen } \\
\text { sonuçlar küçük firmalar ile } \\
\text { ilgili önceki çalışmalarla } \\
\text { benzerlik göstermektedir. } \\
\text { Ancak büyük firmalar için } \\
\text { belirgin farklılı, inovasyon } \\
\text { için kazanç en azından firma } \\
\text { büyüklüğü koşuluna bağlı } \\
\text { olabilir. Ayrıca önerilen } \\
\text { inovatif zorunluluklara karş1 } \\
\text { firma performans farklıllğgnın } \\
\text { yüksek düzeyine dikkat } \\
\text { edilmelidir. Mutlak doğru } \\
\text { olmamakla birlikte Ar-Ge } \\
\text { faaliyetleri yapan firmaların } \\
\text { büyüm olasılığı daha } \\
\text { yüksektir. }\end{array}$ \\
\hline $\begin{array}{l}\text { Del Monte } \\
\text { ve } \\
\text { Papagni } \\
\text { (2003) }\end{array}$ & $\begin{array}{l}500 \text { İtalyan } \\
\text { İmalat Firmas1, } \\
\text { 1989-1997. }\end{array}$ & $\begin{array}{l}\text { Regresyon } \\
\text { Panel Veri }\end{array}$ & $\begin{array}{l}\text { Firma Boyutu, } \\
\text { Büyüme Oranı, } \\
\text { Verimlilik ve } \\
\text { Verimlilik } \\
\text { Büyüme Oranı, } \\
\text { Kârlılık }\end{array}$ & $\begin{array}{lr}\text { Çalışmanın sonuçları firma } \\
\text { büyümesini } & \text { açılayan } \\
\text { rastlantısal ve } & \text { sistematik } \\
\text { değişkenlerin } & \text { varlığını } \\
\text { doğrulamaktadır. } & \text { Ar-Ge } \\
\text { faaliyetleri yapan } & \text { firmaların } \\
\text { satışlarındaki } & \text { büyüme } \\
\text { yapmayan firmalara nispeten } \\
\text { daha fazla olup ar-ge } \\
\begin{array}{l}\text { yatırımları ile büyüme } \\
\text { arasında pozitif yönlü bir } \\
\text { ilişkiye rastlanmıştır. }\end{array} \\
\end{array}$ \\
\hline $\begin{array}{l}\text { Coad } \\
\text { ve } \\
\text { Rao } \\
(2008)\end{array}$ & $\begin{array}{l}\text { İleri } \\
\text { Teknolojiye } \\
\text { Sahip } \\
\text { Amerikan } \\
\text { Firmaları, } \\
\text { 1963-1998. }\end{array}$ & Regresyon & $\begin{array}{l}\text { Patent Sayıs1, } \\
\text { Yenilikçilik, } \\
\text { Ar-Ge } \\
\text { Harcaması, } \\
\text { Satışlar. }\end{array}$ & $\begin{array}{lrr}\text { Az sayıda } & \text { hızlı büyüyen } \\
\text { süperstar firmalar için } \\
\text { inovasyon büyük önem } \\
\text { taşımaktadır. Birçok firma } \\
\text { için yapılan ar-ge yatırımları } \\
\text { ve patentler } r \text { düşük } \\
\text { performansa neden olmakta } \\
\text { ve satışların artışını olumsuz } \\
\text { etkilemektedir. Bunun sebebi } \\
\text { de teknolojik yeniliklerin } \\
\text { doğası gereği belirsizlik } \\
\text { içermesi ve ar-ge giderlerinin } \\
\text { ar-ge yatırımlarına } \\
\text { dönüştürülmesinin her zaman } \\
\text { mümkün olmamasıdır. }\end{array}$ \\
\hline $\begin{array}{c}\text { Cassia, } \\
\text { Colombelli } \\
\text { ve } \\
\text { Paleari } \\
\text { (2009) }\end{array}$ & $\begin{array}{l}\text { Londra } \\
\text { Borsasına } \\
\text { Kayitlı } \\
\text { Firmalar, } \\
\text { 1995-2006 }\end{array}$ & $\begin{array}{l}\text { Genelleştiril } \\
\text { miş } \\
\text { Momentler } \\
\text { Yöntemi } \\
\text { (GMM) }\end{array}$ & \begin{tabular}{|l} 
Firma \\
Büyümesi \\
(Satışların \\
Doğal \\
Logaritması), \\
Büyüklük, \\
Firma Yaşı, \\
Üniversite \\
Sanayi \\
İşbirliği, \\
Öğrenci Sayısı, \\
Araştırma \\
\end{tabular} & $\begin{array}{l}\text { Üniversiteler için mevcut } \\
\text { araştırma fonu miktarı firma } \\
\text { büyümesini pozitif yönde } \\
\text { etkilerken, üniversitenin girdi } \\
\text { ve çıtı etkisi (akademik } \\
\text { bilgi) firma büyümesini } \\
\text { etkilememektedir. Bölgedeki } \\
\text { öğrenci sayısı ile firma } \\
\text { büyümesi arasında ilişki } \\
\text { anlamlı ve pozitif yönde } \\
\text { tespit edilmiştir. Son olarak } \\
\text { büyüklük ile firma büyümesi }\end{array}$ \\
\hline
\end{tabular}




\begin{tabular}{|c|c|c|c|c|}
\hline & & & $\begin{array}{l}\text { Fonu, Ar-Ge } \\
\text { Harcamalarının } \\
\text { Gayrisafi } \\
\text { Yurtiçi } \\
\text { Hasılaya Oranı } \\
\text { ve Patentler. } \\
\end{array}$ & $\begin{array}{l}\text { arasındaki ilişki istatistiksel } \\
\text { olarak anlamlı saptanmıştır. }\end{array}$ \\
\hline $\begin{array}{l}\text { Karacaer, } \\
\text { Aygün ve İç } \\
\text { (2009) }\end{array}$ & $\begin{array}{l}\text { BİST’te İşlem } \\
\text { Görün } 84 \\
\text { Firma, 2005- } \\
2006 .\end{array}$ & $\begin{array}{l}\text { Regresyon } \\
\text { ve } \\
\text { Korelasyon } \\
\text { Analizi. }\end{array}$ & \begin{tabular}{|l} 
Hisse Senedi \\
Getirisi, Aktif \\
Kârlılığı \\
(ROA), Ar-Ge \\
Giderleri, Ge \\
Yoğunluğu \\
(Ar-Ge/Net \\
Satışlar), \\
Büyüklük \\
(Aktiflerin \\
doğal \\
logaritması), \\
Firmada \\
Çalışan \\
Personel \\
Sayısı. \\
\end{tabular} & $\begin{array}{l}\text { İki performans ölçütü (Hisse } \\
\text { senedi getirisi ve aktif } \\
\text { kârlılığı) } \quad \text { ile } \\
\text { harcamaları arasında pozitif } \\
\text { ve istatistiksel olarak anlamlı } \\
\text { sonuçlar elde edilmiştir. }\end{array}$ \\
\hline $\begin{array}{l}\text { García- } \\
\text { Manjón ve } \\
\text { Romero- } \\
\text { Merino } \\
\text { (2012) }\end{array}$ & $\begin{array}{l}18 \text { Farklı } \\
\text { Avrupa } \\
\text { Ülkesinden En } \\
\text { Yüksek Ar-Ge } \\
\text { Harcaması } \\
\text { Yapan } 1.000 \\
\text { Firma, } \\
\text { 2003-2007. }\end{array}$ & $\begin{array}{l}\text { Regresyon, } \\
\text { Quantile } \\
\text { Regresyon, } \\
\text { GMM. }\end{array}$ & $\begin{array}{l}\text { Büyüme (Net } \\
\text { Satışların } \\
\text { Logaritmasının } \\
\text { Farkı), Firma } \\
\text { Yenilikçiliği } \\
\text { (Ar-Ge / Net } \\
\text { Satışlar), } \\
\text { Satışlar, }\end{array}$ & 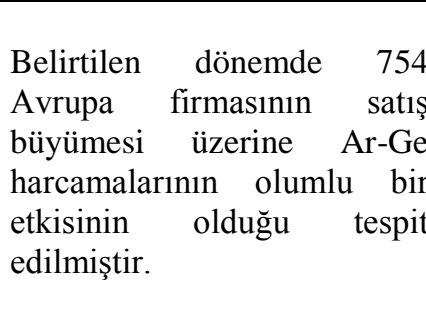 \\
\hline $\begin{array}{l}\text { Choi } \\
\text { ve } \\
\text { Williams } \\
\text { (2013) }\end{array}$ & $\begin{array}{l}\text { Kore ve Çin’de } \\
\text { Mikroelektroni } \\
\text { k, ilaç ve } \\
\text { Telekomünikas } \\
\text { yon Sektöründe } \\
\text { Faaliyet } \\
\text { Gösteren } 90 \\
\text { Firma, } \\
\text { 2000-2003. }\end{array}$ & $\begin{array}{l}\text { Panel Veri, } \\
\text { Regresyon }\end{array}$ & $\begin{array}{l}\text { Satışların } \\
\text { Büyümesi, } \\
\text { Aktif Kârlılığı } \\
\text { (ROA), Ar- } \\
\text { Ge/Satışlar, } \\
\text { Patent } \\
\text { Yoğunluğu } \\
\text { (Patent } \\
\text { Sayısı/Satışlar), } \\
\text { Yenilikçilik } \\
\text { Yoğunluğu ve } \\
\text { Çeşitliliği, } \\
\text { Firma Boyutu } \\
\text { ve Yaşı, } \\
\text { Kaldıraç Oranı }\end{array}$ & $\begin{array}{l}\text { Kore ve Çin firmalarının } \\
\text { Satış büyümesi ve ROA } \\
\text { üzerinde Ar-Ge yoğunluğu } \\
\text { istatistiksel olarak anlamlı } \\
\text { değilken, patent yoğunluğu } \\
\text { istatistiksel olarak anlamlıdır. } \\
\text { Yenilikçilik yoğunluğu Çin } \\
\text { firmalarına kıyasla Kore } \\
\text { firmaları için daha önemli } \\
\text { finansal performansın } \\
\text { belirleyicisidir. Yenilikçilik } \\
\text { çeşitliliği Çinli firmalar için } \\
\text { finansal performansın güçlü } \\
\text { belirleyicisi iken Kore } \\
\text { firmaları için değildir. Komşu } \\
\text { ülkelerin yenilik faaliyetleri } \\
\text { Çin firmalarına kıyasla Kore } \\
\text { firmalarının finansal } \\
\text { performansı üzerinde güçlü } \\
\text { bir etkiye sahiptir. }\end{array}$ \\
\hline $\begin{array}{l}\text { Ünal } \\
\text { ve } \\
\text { Seçilmiş } \\
\text { (2014) }\end{array}$ & $\begin{array}{l}29 \text { Gaziantep } \\
\text { Firmas1, } \\
\text { 2005-2010 }\end{array}$ & $\begin{array}{l}\text { Panel Veri } \\
\text { Regresyon, } \\
\text { Panel } \\
\text { GMM. }\end{array}$ & $\begin{array}{l}\text { Ar-Ge } \\
\text { Harcamaları, } \\
\text { Dönem Net } \\
\text { Kârı, Net Satış } \\
\text { Hasılatı. }\end{array}$ & $\begin{array}{l}\text { Ar-Ge harcamalarının net } \\
\text { satış hasılatı üzerinde, dönem } \\
\text { net kârının da Ar-Ge } \\
\text { harcamaları üzerinde etkisi } \\
\text { olduğu sonucu tespit } \\
\text { edilmiştir. }\end{array}$ \\
\hline
\end{tabular}




\begin{tabular}{|c|c|c|c|c|}
\hline $\begin{array}{l}\text { Kocamış ve } \\
\text { Güngör } \\
\text { (2014) }\end{array}$ & $\begin{array}{l}\text { BİST Teknoloji } \\
\text { Sektöründe } \\
\text { İşlem Gören } 16 \\
\text { Firma, } \\
\text { 2009-2013 }\end{array}$ & Regresyon & \begin{tabular}{|l} 
Ar-Ge \\
Harcamaları, \\
Faaliyet \\
Kâr/Zararı, \\
Vergi Öncesi \\
Kâr/Zararı, \\
Dönem Net \\
Kâr/Zararı. \\
\end{tabular} & $\begin{array}{l}\text { Ar-Ge giderleri ile şirketin } \\
\text { faaliyet kârı, vergi öncesi kâr } \\
\text { ve dönem net kârından oluşan } \\
\text { kârlılık değerleri arasında } \\
\text { pozitif yönlü anlamlı bir ilişki } \\
\text { olduğu tespit edilmiştir. }\end{array}$ \\
\hline $\begin{array}{c}\text { Özcan, } \\
\text { Ağırman ve } \\
\text { Y1lmaz } \\
(2014)\end{array}$ & $\begin{array}{l}\text { BİST’te kayıtlı } \\
9 \text { Ar-Ge } \\
\text { Firmas1, } \\
\text { 2000:Q1- } \\
\text { 203:Q4 }\end{array}$ & $\begin{array}{l}\text { Panel Veri } \\
\text { Analizi } \\
\text { (Pedroni ve } \\
\text { Kao Eş- } \\
\text { Bütünleşme } \\
\text { Testi, } \\
\text { Johansen- } \\
\text { Fisher } \\
\text { Panel Eş- } \\
\text { Bütünleşme } \\
\text { Testi, } \\
\text { Granger } \\
\text { Nedensellik } \\
\text { Testi, Sabit } \\
\text { ve Tesadüfi } \\
\text { Etkiler } \\
\text { Modeli) }\end{array}$ & $\begin{array}{l}\text { Hisse Senedi } \\
\text { Getirisi, Ar-Ge } \\
\text { Gideri. }\end{array}$ & $\begin{array}{l}\text { Araştırmanın sonuçları büyük } \\
\text { ölçüde hisse senedi getirileri } \\
\text { ile Ar-Ge harcamaları } \\
\text { arasında olumlu ve güçlü bir } \\
\text { ilişkinin var olduğunu } \\
\text { göstermektedir. }\end{array}$ \\
\hline $\begin{array}{l}\text { Öztürk } \\
\text { ve } \\
\text { Zeren } \\
\text { (2015) }\end{array}$ & $\begin{array}{l}26 \text { Türk İmalat } \\
\text { Firmas1, } \\
\text { 2007-2014 }\end{array}$ & $\begin{array}{l}\text { Panel Veri } \\
\text { Analizi, } \\
\text { Uzun } \\
\text { Dönemli } \\
\text { Eşbütünleş } \\
\text { me Analizi. } \\
\end{array}$ & $\begin{array}{l}\text { Ar-Ge } \\
\text { Harcamaları, } \\
\text { Satış } \\
\text { Büyümesi, }\end{array}$ & $\begin{array}{l}\text { Ar-Ge Harcamalarının imalat } \\
\text { sanayiinde satış büyümesi } \\
\text { üzerinde pozitif yönde bir } \\
\text { etkiye sahip olduğu tespit } \\
\text { edilmiştir. }\end{array}$ \\
\hline $\begin{array}{l}\text { Demirgüneş } \\
\text { ve Üçler } \\
\text { (2016) }\end{array}$ & $\begin{array}{l}\text { Borsa } \\
\text { İstanbul'da } \\
\text { İşlem Gören } \\
\text { İmalat } \\
\text { Firmaları, } \\
\text { 1992:Q1- } \\
\text { 2013:Q3 }\end{array}$ & $\begin{array}{l}\text { Panel Veri } \\
\text { Analizi, } \\
\text { Eşbütünleş } \\
\text { me Analizi. }\end{array}$ & $\begin{array}{l}\text { Büyüme } \\
\text { (Satışlardaki } \\
\text { yüzdesel } \\
\text { değişim), Ar- } \\
\text { Ge (Ar-Ge } \\
\text { giderlerinin } \\
\text { aktifleştirilmiş } \\
\text { kısmı), Maddi } \\
\text { Olmayan } \\
\text { Duran } \\
\text { Varlıklar, } \\
\text { Faaliyet Nakit } \\
\text { Akımları ve } \\
\text { Kârlılık Oranı. } \\
\end{array}$ & 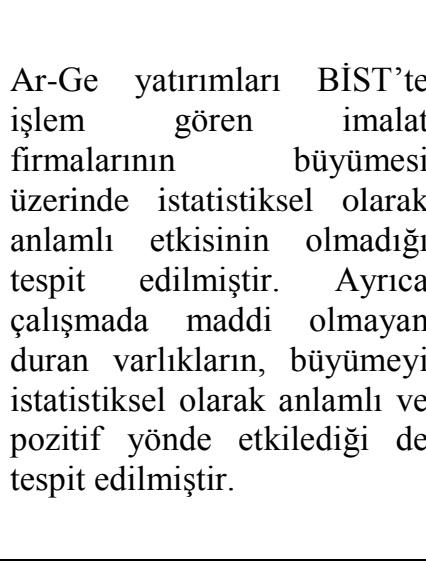 \\
\hline $\begin{array}{c}\text { Işı1k, } \\
\text { Engeloğlu } \\
\text { ve Kılınç } \\
(2016)\end{array}$ & $\begin{array}{l}\text { Borsa } \\
\text { İstanbul'da } \\
\text { İşlem Gören } \\
\text { İmalat Sanayi } \\
\text { Sektöründeki } \\
\text { 30 Firma, } \\
\text { 2008:Q1- } \\
\text { 2014:Q4 }\end{array}$ & $\begin{array}{l}\text { Panel Veri } \\
\text { Analizi, } \\
\text { Havuzlanmı } \\
\text { ş En Küçük } \\
\text { Kareler, } \\
\text { Sabit } \\
\text { Etkiler ve } \\
\text { Rassal } \\
\text { Etkiler } \\
\text { Modeli. }\end{array}$ & $\begin{array}{l}\text { Ar-Ge } \\
\text { Harcamaları, } \\
\text { Faaliyet Kârı, } \\
\text { Net Satışlar, } \\
\text { Ar-Ge } \\
\text { Yoğunluğu } \\
\text { (Ar-Ge/Net } \\
\text { Satışlar), Ar- } \\
\text { Ge Oranı (Ar- } \\
\text { Ge } \\
\text { Harcamaları/Fa } \\
\end{array}$ & $\begin{array}{l}\text { Firmaların Ar-Ge'ye yönelik } \\
\text { miktar bazında yaptığ } \\
\text { harcamaların hem kârlılığa } \\
\text { hem de satışlara olumlu bir } \\
\text { etkisinin olduğu ortaya } \\
\text { konmuştur. Ayrıca Ar-Ge } \\
\text { yoğunluğu ve Ar-Ge oranı ile } \\
\text { kârlılık ve satışlar arasında } \\
\text { anlamlı bir ilişkinin varlığına } \\
\text { rastlanılmamıştır. }\end{array}$ \\
\hline
\end{tabular}




\begin{tabular}{|c|l|l|l|l|}
\hline & & & $\begin{array}{l}\text { aliyet } \\
\text { Giderleri). }\end{array}$ & \\
\hline $\begin{array}{c}\text { Akgün ve } \\
\text { Akgün } \\
\text { (2016) }\end{array}$ & $\begin{array}{l}\text { Aselsan A.Ş. } \\
\text { 2006:Q1- } \\
\text { 2016:Q4 }\end{array}$ & $\begin{array}{l}\text { Regresyon } \\
\text { (En Küçük } \\
\text { Kareler), } \\
\text { Johansen } \\
\text { Eşbütünleş } \\
\text { me Testi. }\end{array}$ & $\begin{array}{l}\text { Ar-Ge } \\
\text { Harcamaları, } \\
\text { Net Esas } \\
\text { Faaliyet Kâr1. }\end{array}$ & $\begin{array}{l}\text { Ar-Ge harcamaları ile net } \\
\text { esas faaliyet kârı arasinda } \\
\text { uzun dönemli ve aynı yönde } \\
\text { bir ilişkinin olduğu tespit } \\
\text { edilmiştir. }\end{array}$ \\
\hline
\end{tabular}

\section{ARAŞTIRMA MODELİ VE KULLANILAN GİRDİ İLE ÇIKTILAR}

Çalışmanın bu bölümünde, araştırmaya temel olan veri zarflama analizi tanımlanarak, kullanılan veri zarflama modelleri tanıtılmakta ve çalışmada yer verilen girdi ve çıktılar açıklanmaktadır.

\section{Veri Zarflama Modeli}

$\mathrm{Bu}$ çalışmada Türkiye'deki BIST Teknoloji Endeksinde yer alan firmaların Ar-Ge harcamalarının performans etkinliği veri zarflama analizi ile değerlendirilmektedir. Veri zarflama analizi, geleneksel etkinlik ölçüm yöntemlerinin gerektirdiği bazı varsayım ve kısıtlamalar olmaksızın etkinlik analizi yapmaya olanak vermektedir. Etkinlik ölçmede kullanılan parametrik veya istatistiksel yöntemlerin aksine veri zarflama analizi, üretim fonksiyonun altında yatan ön koşul niteliğindeki güçlü varsayımlara dayanmamaktadır (Tarım ve Karan, 2001: 67-68).

Aynı girdileri kullanarak aynı çıktıları üreten homojen karar birimlerinin göreli etkinliklerinin belirlenmesinde kullanılabilen veri zarflama analizinde bir karar biriminin göreli etkinliği; toplam ağırlıklı çıktıların toplam ağırlıklı girdilere oranı olarak tanımlanmaktadır (Tarım, 2001: 175). Veri zarflama analizinde, karar birimleri kümesini oluşturan birimlerin göreli etkinliği belirlenirken, oluşturulan bir etkinlik (üretim) sınırı referans alınmaktadır. Belirli bir girdi miktarı ile en iyi çıktının elde edilebildiği veya belirli bir miktar çıktının minimum girdi ile elde edilebildiği karar birimleri vektöründen elde edilen düzlem ile bir karar birimi arasındaki uzaklık o karar biriminin etkinsizlik ölçütü olarak değerlendirilmektedir (Alexander, 2007: 98; Anderson v.d., 2002: 599).

İki temel veri zarflama modeli mevcut olup bunlar CCR ve BCC modelleridir. Charnes v.d.(1978) tarafından geliştirilen doğrusal programlama esaslı CCR veri zarflama analizi modeli ile ölçeğe göre sabit getiri varsayımı altında, karar birimlerinin göreli (toplam) teknik etkinliklerini belirlenmektedir. Ölçeğe göre sabit getiri varsayımına dayanan CCR modelinden sonra ölçeğe göre değişken getiri varsayımına dayanan BCC modeli ortaya çıkmıştır. Banker v.d. (1984: 1078), CCR modeline yeni bir değişken ekleyerek karar 
birimlerinin faaliyetlerinin; ölçeğe göre artan, sabit veya azalan getiri bölgelerinde olup olmadığını belirlemeye olanak veren BCC modelini geliştirmişlerdir.

Teknik etkinlik, üretim sürecinde belirli bir girdi bileşimi ile maksimum çıktının elde edilmesi veya en az girdi kullanarak belirli bir çıktı bileşiminin elde edilmesidir.

Toplam teknik etkinlik, çıktıları azaltmak zorunda kalmadan girdi kullanımının azaltılamayacağı bir üretim noktasında bulunmak anlamına gelmektedir Yani, girdi kullanımını azaltabilmek için, üretim miktarında azaltma yapılması gereken üretim düzeyine ulaşıldığında toplam teknik etkinlik gerçekleşmektedir (Topuz v.d., 2005: 1970). Toplam (teknik) etkinlik, ölçeğe göre sabit getiri varsayımı altında, girdi veya çıktı yöneliminden bağımsız olarak hesaplanırken, (saf) teknik etkinlik ise girdi veya çıktı yönelimi belirleyici olmak kaydı ile ölçeğe göre değişken getiri varsayımı altında hesaplanmaktadır (Tarım, 2001: 35). Girdi yönelimi, belirli bir çıktı miktarının en az girdi miktarı ile elde edilebilmesi durumunu ifade ederken, çıktı yönelimi belirli bir girdi miktarı ile en fazla çıktının elde edilebilmesi durumunu ifade etmektedir. Ölçeğe göre sabit getirinin söz konusu olmadığ1 durumlarda, yani ölçeğe göre değişken getiri varsayımı altında, "Toplam teknik etkinlik (TTE)"; 1) "saf teknik etkinlik (pure technical efficiency)", 2) "ölçek etkinliği (scale efficiency)" olmak üzere iki unsurdan oluşmaktadır. Saf teknik etkinlik (STE), ölçeğe göre değişken getiri varsayımı altında girdilerin etkin kullanımını ifade ederken, ölçek etkinliği (ÖE) ise optimal ölçek büyüklügünde veya ölçeğe göre sabit getiride faaliyet gösterilmesini ifade etmektedir (Anderson v.d., 2002: 600).

Firma yöneticileri, gider oran, yönetim giderleri, Ar-Ge giderleri gibi girdilerin düzeyleri üzerinde kontrol sahibi oldukları için, bu çalışmada girdi yönelimli veri zarflama analizi modeli kullanılmıştır.

Ölçek büyüklüğü fazla olan firmalar büyük olmanın avantajı ile Ar-Ge harcamaları için düşük birim maliyetlere sahip olabilirler. Yani firmalar ölçeğe göre artan getiride faaliyet gösterebilirler. Diğer taraftan, çok büyük firmaların finansal kaynak sıkıntısı olmayabileceği için devasa Ar-Ge yatırımlarına cesaret etmeleri birim maliyetlerini yüksek de tutabilecektir. $\mathrm{Bu}$ durumda ölçekten kaynaklanan dezavantajlara sahip olabilir ve ölçeğe göre azalan getiride faaliyet gösterebilirler. Bu nedenle, çalışmamızda Borsa İstanbul Teknoloji endeksinde yer alan firmaların Ar-Ge etkinliklerini değerlendirmek için ölçeğe göre sabit getiri varsayımına dayanan CCR veri zarflama analizi modeli ile birlikte, ölçeğe göre değişen getiri varsayımına dayanan BCC veri zarflama analizi modeli de kullanılmıştır. Bu şekilde, ölçeğe göre sabit, ölçeğe göre artan ve ölçeğe göre azalan getiri özelliği teknoloji firmaları belirlenebilmiştir. 


\section{Kullanılan Girdi ile Çıktılar}

BIST Teknoloji endeksinde yer alan firmaların Ar-Ge harcamalarının performans etkinliklerinin değerlendirildiği bu çalışmada veri zarflama modeli için 2 adet girdi ve 2 adet çıtı tespit edilmiştir.

GÍRDİ1: ArGe Yoğunluğu $=\frac{\text { Araştırma Geliştirme Giderleri }}{\text { Net Satışlar }}$

GÍRDİ2: ArGe/Aktifler $=\frac{\text { Araştırma Geliștirme Giderleri }}{\text { Toplam Aktifler }}$

CIKTI1: Aktif Karlılık Oranı $=\frac{\text { Dönem Net Karı }}{\text { Toplam Aktifler }}$

CIKTI2: PD $/ \mathrm{DD}$ Oramı $=\frac{\text { Toplam Piyasa Değerj }}{\text { Özkaynaklar }}$

Yukarıdaki değişkenlerden Ar-Ge Yoğunluğu ve Ar-Ge/Aktifler veri zarflama analizindeki girdi değişkeni olup, çıktı değişkenleri aktif karlılık oranı ve piyasa değeri/defter değeri oranıdır.

Ar-Ge yatırımlarının performans üzerindeki etkisinin ortaya çıkmasının zaman alması nedeniyle veri zarflama analizlerinde girdi değişkenleri bir önceki yıl sonu değerleriyle hesaplanmıştır. Örneğin, Ar-Ge Yoğunluğu değişkeni ve Ar-Ge/Aktifler değişkeni 2015 veri zarflama analizinde 2014 değeriyle. Çıktı değişkenleri ise, analizlere ilgili analiz yılının değerleriyle dahil edilmiştir. 2 girdi ve 2 çıktıdan oluşan, girdi yönelimli, arşimedgil olmayan CCR ve BCC modelleri araştırma dönemimizi oluşturan 2013-2015 dönemindeki her y1l için ayrı ayrı belirlenmiştir. Yıllar boyunca bütün değişkenlerin ortalamasını alarak tek bir veri zarflama modeli oluşturmaktansa, her yıl için ayrı ayrı veri zarflama analizleri yapmak daha doğru bulunmaktadır (Topuz vd., 2005: 1971). Ölçeğe göre sabit getiri esasına dayanan CCR modeli ile menkul firmaların "toplam teknik etkinlikleri” belirlendikten sonra, ölçeğe göre değişken getiri esasına dayanan BCC modeli ile "saf teknik etkinlikler" belirlenmiştir. Etkinlik değerleri arasında var olan Toplam Teknik Etkinlik = Saf Teknik etkinlik x Ölçek Etkinliği (Tarım, 2001: 34-36) ilişskisi kullanılarak firmaların “ölçek etkinlikleri” de hesaplanmıştır. 


\section{VERI SETİ}

Firmaların Ar-Ge harcamalarının etkinliklerinin veri zarflama analizi ile değerlendirilebilmesi için belirlenen girdiler ve çıktılar Borsa İstanbul'da (BİST) işlem gören teknoloji endeksindeki (XUTEK) 7 firmanın ${ }^{1}$ Kamuoyunu Aydınlatma Platformu'nun web sayfasında (www.kap.gov.tr) yer alan finansal tablolarından yararlanarak elde edilmiştir. Araştırma dönemi olarak, 2013, 2014 ve 2015 yılları seçilmiştir. Girdi değişkenlerinin 2012 yılına ait değerleri ile çıktı değişkenlerinin 2013 yılına ait değerleri kullanılarak "2013 yılı modeli” oluşturulmuştur. Girdi değişkenlerinin 2013 yılına ait değerleri ile çıktı değişkenlerinin 2014 yılına ait değerleri kullanılarak "2014 y1lı modeli” oluşturulmuştur. Benzer şekilde, Girdi değişkenlerinin 2014 yılına ait değerleri ile çıktı değişkenlerinin 2015 yılına ait değerleri “2015 yılı modeli’ni oluşturmaktadır.

\section{MODEL SONUÇLARI VE BULGULAR}

2013, 2014 ve 2015 y1lları için 7 adet teknoloji firması için oluşturulan girdi yönelimli, arşimedgil olmayan veri zarflama modelleri hem CCR modeli, hem de BCC modeli temelinde çözülerek toplam teknik etkinlik ve saf etkinlik puanları elde edilmiştir. Modellerin çözümü için EMS (Efficiency Measurement System) yazılımının 1.3 versiyonu kullanılmıştır.

Tablo 2. 2013 Yılına Ait Veri Zarflama Modellerinin Sonuçları

\begin{tabular}{|l|l|l|l|l|l|}
\hline Karar Birimi & $\begin{array}{c}\text { Toplam } \\
\text { Teknik } \\
\text { Etkinlik } \\
\text { (CCR) }\end{array}$ & $\begin{array}{c}\text { Saf Teknik } \\
\text { Etkinlik } \\
\text { (BCC) }\end{array}$ & $\begin{array}{c}\text { Ölçek } \\
\text { Etkinliği }\end{array}$ & $\begin{array}{c}\text { Ölçeğe } \\
\text { Göre Getiri }\end{array}$ \\
\hline 1 & ALCTL & $62,20 \%$ & $77,09 \%$ & $80,68 \%$ & Artan \\
\hline 2 & ASELS & $7,84 \%$ & $8,66 \%$ & $90,53 \%$ & Artan \\
\hline 3 & KAREL & $3,39 \%$ & $4,16 \%$ & $81,49 \%$ & Artan \\
\hline 4 & LINK & $3,60 \%$ & $7,21 \%$ & $49,93 \%$ & Azalan \\
\hline 5 & LOGO & $1,76 \%$ & $\mathbf{1 0 0 , 0 0 \%}$ & $1,76 \%$ & Azalan \\
\hline 6 & NETAS & $71,53 \%$ & $\mathbf{1 0 0 , 0 0 \%}$ & $71,53 \%$ & Artan \\
\hline 7 & TTKOM & $\mathbf{1 0 0 , 0 0 \%}$ & $\mathbf{1 0 0 , 0 0 \%}$ & $\mathbf{1 0 0 , 0 0 \%}$ & Sabit \\
\hline
\end{tabular}

Tablo 1'de yer alan 2013 yılı için veri zarflama modellerinin sonuçları arasından CCR modeli ile elde edilen toplam teknik etkinlik puanlarına bakıldığında, toplam teknik etkinliğe sahip olan (kalın punto ile belirlenmiş) sadece 1 adet firma olduğu görülmektedir. Bu firma, 2013 yılında çıktıları azaltma fedakârlığı göstermeden Ar-Ge girdilerini azaltamayacak duruma gelmiştir. BCC modeli ile elde edilen saf teknik etkinlik puanlarına bakıldığında \% 100 saf teknik etkinliğe sahip 3 adet firmanın Ar-Ge girdilerini etkin olarak kullandıkları anlaşılmaktadır. Ölçek etkinliği puanlarına bakıldığında 1 firmanın ölçek etkinliğine sahip olduğu görülmektedir. Ölçek etkinliğine sahip olan TTKOM 2013 yılında ölçeğe göre sabit getiride, başka bir ifadeyle optimal ölçek büyüklüğünde faaliyet göstermektedir Ölçek

\footnotetext{
${ }^{1}$ Bu firmalar şunlardır: ALCTL, ASELS, KAREL, LINK, LOGO, NETAS, TTKOM.
} 
etkinliğine sahip olmayan firmalardan 2 adeti ölçeğe göre azalan getiri özelliği gösterirken 4 adeti ölçeğe göre artan getiri özelliği göstermektedir. Ölçeğe göre azalan getiri, firmaların ArGe girdi miktarındaki artışa göre daha az performans artışı elde ettiklerini göstermektedir. Ölçeğe göre artan getiri ise, firmaların Ar-Ge girdilerini arttırarak, girdi artış oranına kıyasla daha fazla performans artışı sağlayabildiklerini göstermektedir.

Tablo 3. 2014 Yılına Ait Veri Zarflama Modellerinin Sonuçları

\begin{tabular}{|l|l|l|l|l|l|}
\hline Karar Birimi & $\begin{array}{c}\text { Toplam } \\
\text { Teknik } \\
\text { Etkinlik } \\
\text { (CCR) }\end{array}$ & $\begin{array}{c}\text { Saf Teknik } \\
\text { Etkinlik } \\
\text { (BCC) }\end{array}$ & $\begin{array}{c}\text { Ölçek } \\
\text { Etkinliği }\end{array}$ & $\begin{array}{c}\text { Ölçeğe } \\
\text { Göre } \\
\text { Getiri }\end{array}$ \\
\hline 1 & ALCTL & $8,09 \%$ & $8,75 \%$ & $92,46 \%$ & Artan \\
\hline 2 & ASELS & $10,24 \%$ & $11,34 \%$ & $90,30 \%$ & Artan \\
\hline 3 & KAREL & $1,90 \%$ & $3,28 \%$ & $57,93 \%$ & Artan \\
\hline 4 & LINK & $1,65 \%$ & $2,14 \%$ & $77,10 \%$ & Artan \\
\hline 5 & LOGO & $3,12 \%$ & $\mathbf{1 0 0 , 0 0 \%}$ & $3,12 \%$ & Azalan \\
\hline 6 & NETAS & $86,30 \%$ & $\mathbf{1 0 0 , 0 0 \%}$ & $86,30 \%$ & Artan \\
\hline 7 & TTKOM & $\mathbf{1 0 0 , 0 0 \%}$ & $\mathbf{1 0 0 , 0 0 \%}$ & $\mathbf{1 0 0 , 0 0 \%}$ & Sabit \\
\hline
\end{tabular}

Tablo 2'de yer alan 2014 yılı için veri zarflama modellerinin sonuçları arasından CCR modeli ile elde edilen toplam teknik etkinlik puanlarına bakıldığında, toplam teknik etkinliğe sahip olan (kalın punto ile belirlenmiş) sadece 1 adet firma olduğu görülmektedir. 2014'te toplam teknik etkinliğe sahip olan firmanın 2013'te de toplam teknikliğe sahip tek firma olan TTKOM olduğu anlaşılmaktadır. BCC modeli ile elde edilen saf teknik etkinlik puanlarına bakıldığında saf teknik etkinliğe sahip 3 adet firmanın 2013'te de saf teknik etkinliğe sahip olan firmalar (LOGO, NETAS, TTKOM) olduğu görülmektedir. Toplam teknik etkinlik puanını saf teknik etkinlik puanına bölmek suretiyle elde edilen ölçek etkinliği puanlarına bakıldığında 2013'te olduğu gibi yine sadece TTKOM'un ölçek etkinliğine sahip olduğu görülmektedir. Ölçek etkinliğine sahip olmayan firmalardan 1 adeti (LOGO) ölçeğe göre azalan getiri özelliği gösterirken 5 adeti ölçeğe göre artan getiri özelliği göstermektedir. 2013 'te ölçeğe göre azalan getiri özelliği taşıyan LINK firmasının 2014'te ölçek etkinliğini artırarak ölçeğe göre artan getiri noktasına ulaştığı anlaşılmaktadır. 2014 yılı için 5 adet firma ölçeğe göre artan getiri özelliği taşıdıkları için Ar-Ge girdilerini arttırarak, girdi artış oranına kıyasla daha fazla performans artışı sağlayabildiklerini göstermektedir. 
Tablo 4. 2015 Y1lına Ait Veri Zarflama Modellerinin Sonuçları

\begin{tabular}{|l|l|l|l|l|l|}
\hline Karar Birimi & $\begin{array}{c}\text { Toplam } \\
\text { Teknik } \\
\text { Etkinlik } \\
\text { (CCR) }\end{array}$ & $\begin{array}{c}\text { Saf Teknik } \\
\text { Etkinlik } \\
\text { (BCC) }\end{array}$ & $\begin{array}{c}\text { Ölçek } \\
\text { Etkinliği }\end{array}$ & $\begin{array}{c}\text { Ölçeğe } \\
\text { Göre Getiri }\end{array}$ \\
\hline 1 & ALCTL & $24,22 \%$ & $100,00 \%$ & $24,22 \%$ & Azalan \\
\hline $\mathbf{2}$ & ASELS & $17,49 \%$ & $22,02 \%$ & $79,43 \%$ & Azalan \\
\hline 3 & KAREL & $1,99 \%$ & $2,64 \%$ & $75,38 \%$ & Artan \\
\hline 4 & LINK & $9,98 \%$ & $\mathbf{1 0 0 , 0 0 \%}$ & $9,98 \%$ & Azalan \\
\hline 5 & LOGO & $6,08 \%$ & $\mathbf{1 0 0 , 0 0 \%}$ & $6,08 \%$ & Azalan \\
\hline $\mathbf{6}$ & NETAS & $\mathbf{1 0 0 , 0 0 \%}$ & $\mathbf{1 0 0 , 0 0 \%}$ & $\mathbf{1 0 0 , 0 0 \%}$ & Sabit \\
\hline 7 & TTKOM & $95,64 \%$ & $\mathbf{1 0 0 , 0 0 \%}$ & $95,64 \%$ & Azalan \\
\hline
\end{tabular}

Tablo 3, 2015 y1lı için veri zarflama modellerinin sonuçlarına yer vermektedir. CCR modeli sonuçları, toplam teknik etkinliğe sahip olan tek firmanın NETAS olduğunu göstermektedir. Toplam teknik etkinlik puanını saf teknik etkinlik puanına bölmek suretiyle elde edilen ölçek etkinliği puanlarına bakıldığında yine sadece NETAS firmasının ölçek etkinliğine sahip olduğu görülmektedir. Veri zarflama analizi etkinlik ölçümünü firmaların birbirlerine göre belirlediği için diğer firmaların tamamen etkinsiz olduğunu ifade etmek doğru olmayacaktır. Ancak tam etkinliğe sahip olan firmaya kıyasla göreli etkinsiz oldukları ifade edilebilir. Bir önceki yıl ölçeğe göre artan getiride faaliyet gösteren 3 firmanın (ALCTL, ASELS ve LINK) ölçek etkinlikleri azalıp, 2015'te ölçeğe göre azalan getiri noktasına geçmişlerdir. TTKOM da 2013 ve 2014'te ölçeğe göre sabit getiride iken 2015'te ölçek etkinliği azalmış ve ölçeğe göre azalan getiri noktasına geçmiştir. Yani 2015'te TTKOM’un Ar-Ge girdi artışı oranına kıyasla finansal performans artışı daha düşük olarak gerçekleşmiştir. Ölçeğe göre azalan getiri noktasında bulunan firmaların Ar-Ge harcama artışında daha temkinli olmaları gerektiği söylenebilir.

Tablo 5. Y1llar İtibariyle Firmaların Etkinlik Ortalamaları

\begin{tabular}{|c|c|c|c|}
\hline Yıl & Toplam Teknik Etkinlik & Saf Teknik Etkinlik & Ölçek Etkinliği \\
\hline $\mathbf{2 0 1 3}$ & $\% 35,76$ & $\% 56,73$ & $\% 67,99$ \\
\hline $\mathbf{2 0 1 4}$ & $\% 30,19$ & $\% 46,5$ & $\% 72,46$ \\
\hline $\mathbf{2 0 1 5}$ & $\% 36,49$ & $\% 74,95$ & $\% 55,82$ \\
\hline
\end{tabular}

Yukarıda yer alan Tablo 4'te 2013-2015y1lları arasında teknoloji firmalarının Ar-Ge harcamaları konusundaki genel etkinlik durumu ile ilgili bilgiler yer almaktadır.

Tablo 4 incelendiğinde saf teknik etkinlik ortalamasının önce azaldığı son yılda ise arttığı görülmektedir. Bu durum firmaların Ar-Ge harcamalarının teknik olarak etkinliğini artırdığını gösterirken, 2015'teki ölçek etkinliği düzeyi, firmaların optimal ölçek büyüklüğünden uzaklaşmış olduklarını göstermektedir. 


\section{SONUÇ}

Bu çalışmada, 2013-2015 döneminde Türkiye’deki BIST Teknoloji Endeksinde (XUTEK) yer alan firmaların Ar-Ge harcamalarının performans etkinliği veri zarflama analizi ile değerlendirilmiştir. 2013, 2014 ve 2015 yılları için 7 adet teknoloji firması için Ar-Ge Yoğunluğu ve Ar-Ge/Aktifler değişkenlerinin iki girdi, Aktif Karlılık Oranı ve PD/DD Oranı değişkenlerinin iki çıktı olarak yer aldığı veri zarflama modelleri kullanılmıştır. Veri zarflama analizinin sonuçları 2013 ve 2014 yılında TTKOM'un, 2015 yılında ise NETAS'ın \% 100 toplam teknik etkinliğine sahip olduğunu ortaya koymuştur. 2013 ve 2014'te üç firmanın (LOGO, NETAS VE TTKOM), 2015'te beş firmanın (ALCTL, LINK, LOGO, NETAS ve TTKOM) saf teknik etkinlik puanı \% 100 olmasına rağmen diğer firmaların saf teknik etkinlik puanlarının çok düşük olduğu ortaya çıkmıştır. Veri zarflama analizi her bir karar biriminin mutlak etkinliğini ölçmeyip, bütün karar birimlerinin etkinliklerini göreli olarak ortaya koyduğu için, teknoloji firmalarının tamamen etkin ya da etkinsiz olduğunu söylemek mümkün değildir. Analiz sonuçları, 2013 ve 2014'te TTKOM'un, 2015'te ise NETAS'ın tam etkinliğe sahip olduğunu göstermektedir. Dolayısıyla veri zarflama analizi sonuçlarına göre diğer firmalar bu iki firmayı referans almalıdır. Üç yıllık analiz döneminde bu iki firmanın optimal ölçek büyüklüğünde veya ona çok yakın bir düzeyde faaliyette bulundukları ortaya çıkmıştır. Diğer beş firmadan dördünün ölçek etkinlik düzeyi 2013'ten 2015'e bir azalma göstermişken sadece LOGO'nun ölçek etkinliği düzeyinin artmış olması söz konusudur. Ancak LOGO'nun 2013'teki ölçek etkinliği düzeyinin çok düşük olup, 2015'te etkinlik düzeyinin yine tek haneli bir rakamda kalmış olması bu artışı çok anlamlı kılmamaktadır. Genel olarak değerlendirildiğinde firmaların saf teknik etkinlik düzeylerinin göreli olarak yüksek olduğu ve 2015'te beş firmanın tam saf teknik etkinliğe sahip oldukları görülmektedir. Dolayısıyla, firmaların toplam teknik etkinliklerinin artırmak için genel olarak ölçek etkinliklerini arttırmaları gerektiği söylenebilir.

Veri zarflama analizi dışındaki diğer yöntemler kullanılarak Ar-Ge harcamaları ile firma performansı arasındaki ilişki bundan sonra yapılacak çalışmalar için araştırma konusu olabilir. Yapılacak olan çalışmalarda sektörel bir kıyaslama yapılabilir. Ayrıca yapılan Ar-Ge harcamalarının firma performansını artırıp artırmadığı da araştırmacılar tarafından araştırılabilir.

\section{KAYNAKLAR}

Akgün, Ali - Akgün, Özlem (2016). "İşletmelerde Ar-Ge Harcamalarının Kârlılığa Etkisi: ASELSAN Örneği”, Selçuk Üniversitesi, Sosyal ve Teknik Araştırmalar Dergisi, Sayı:12, ss. 1-12.

Alexander, Michael (2007), “Complex Decision Making using Non-Parametric Data Envelopment Analysis (Chapter 6)”, Qudrat-Ullah, Hassan - Spector, J.Michael Davidsen, I. Paal (Ed.), Complex Decision Making, Springer, pp. 97-111. 
Anderson, Randy I - Fok, Robert - Springer, Thomas - Webb, James (2002). “Technical Efficiency and Economies Of Scale: A Non-Parametric Analysis Of REIT Operating Efficiency”, European Journal of Operational Research, 139, pp. 598-612.

Banker, Rajiv. D - Charnes, A - Cooper, William W (1984), "Some Models for Estimating Technical and Scale Inefficiencies in Data Envelopment Analysis, Management Science, 30(9), pp. 1078-1092.

Cassia, Lucio - Colombelli, Alessandra - Paleari, Stefano (2009). "Firms’ Growth: Does the Innovation System Matter?”, Structural Change and Economic Dynamics, 20, pp. 211220 .

Charnes, Abraham - Cooper, William W - Rhodes, Eduardo; (1978), "Measuring the Efficiency of Decisison Making Units”, European Journal of Operational Research, 2, pp. 429-444.

Choi, S. Bong - Williams, Christoper (2013). "Innovation and Firm Performance in Korea and China: a Cross-Context Test of Mainstream Theories”, Technology Analysis \& Strategic Management, 25, pp. 423-444.

Coad, Alex - Rao, Rekha (2008). "Innovation and Firm Growth in High-Tech Sectors: A Quantile Regression Approach”, Research Policy, 37, pp. 633-648.

Del Monte, Alfredo - Papagni, Erasmo (2003). "R\&D and The Growth of Firms: Empirical Analysis of a Panel of Italian Firms”, Research Policy, 32, pp. 1003-1014.

Demirgüneş, H. N. Kartal - Üçler, Gülbahar (2016). “Ar Ge Yatırımları ve Büyüme İmalat Sektörü Üzerine Ampirik Bir Çalışma," İstanbul Üniversitesi İşletme Fakültesi Dergisi, Cilt: 45, Say1: 1, ss. 53-64.

Freel, S. Mark (2000). “Do Small Innovating Firms Outperform Non-Innovators?”, Small Business Economics, 14(3), pp. 195-210.

García-Manjón, V. Juan - Romero-Merino, M. Elena (2012). "Research, Development, and Firm Growth. Empirical Evidence From European Top R\&D Spending Firms”, Research Policy, 41, pp. 1084-1092.

Geroski, Paul. - Toker, S (1996). “The Turnover of Market Leaders in UK Manufacturing Industry, 1979-86”, International Journal of Industrial Organization, 14, pp. 141-158.

Işık, Nihat - Engeloğlu, Özgür - Kılınç, Efe C. (2016). "Araştırma ve Geliştirme Harcamalarının, Kârlılık ve Satışlar Üzerindeki Etkisi: Borsa İstanbul Firmaları Üzerine Bir Uygulama”, Erciyes Üniversitesi İktisadi ve İdari Bilimler Fakültesi Dergisi, 47, ss. 27-46. 
Karacaer, Semra - Aygün, Mehmet - İç, Süleyman (2009). “Araştırma ve Geliştirme Giderlerinin Firma Performansı Üzerindeki Etkisi: İstanbul Menkul Kiymetler Borsası Üzerine Bir İnceleme”, MÖDAV, 2009/2, ss. 65-86.

Kocamış, Uzun Tuğçe - Güngör, Ayşegül (2014). “Türkiye’de Ar-Ge Harcamaları ve Teknoloji Sektöründeki Ar-Ge Giderlerinin Kârlılık Üzerine Etkisi: Borsa İstanbul Uygulaması", Maliye Dergisi, Say1:166, ss. 127-138.

Kónya, Laszlo. (2006). "Exports and Growth: Granger Causality Analysis on OECD Countries with a Panel Data Approach”, Economic Modelling, 23(6), pp. 978-992.

Mowery, C. David (1983). "Industrial Research and Firm Size, Survival, and Growth In American Manufacturing, 1921-1946: An Assessment”, Journal of Economic History, 43(4), pp. 953-980.

Öğredik, Güray (2005). “Araştırma Geliştirme Harcamalarının Gider veya Maliyet Olarak Ticari Kazancın Tespitinde Dikkate Alınacağı Dönem”, Lebib Yalkın Mevzuat Dergisi, Temmuz, ss. 1-16.

Özcan, Muhammet - Ağırman, Ensar - Yılmaz, Ömer (2014). “Ar-Ge Yatırımlarının Hisse Senedi Getirisi Üzerine Etkisi: BİST Teknoloji ve Bilişim Firmaları Üzerine Bir Uygulama”, Maliye Dergisi, 166, Ocak-Haziran, ss. 139-158.

Öztürk, Erkan - Zeren, Feyyaz (2015). "The Impact of R\&D Expenditure on Firm Performance in Manufacturing Industry: Further Evidence From Turkey”, International Journal of Economics and Research, 6, pp. 32-36.

Roper, Stephen (1997). "Product Innovation and Small Business Growth: A Comparison of The Strategies of German, UK and Irish companies”, Small Business Economics, 9, pp. 523-537.

Scherer, M. Frederic (1965). “Corporate Inventive Output, Profits, and Growth”, Journal of Political Economy, 73(3), pp. 290-297.

Tarım, Armağan (2001). Veri Zarflama Analizi: Matematiksel Programlama Tabanlı Göreli Etkinlik Ölçüm Yaklaşımı, İnceleme, “Araştırma, İnceleme, Çeviri Dizisi”, Sayıştay Yayın İşleri Müdürlüğü, Ankara, ss. 222.

Topuz, John C - Darrat, Ali F - Shelor, Roger M (2005), "Technical, Allocative and Scale Efficiencies of REITs: An Empirical Inquiry”, Journal of Business Finance \& Accounting, 32(9) \& (10), pp. 1961-1994.

Ünal, Targan - Seçilmiş, Nisa (2013). “Ar-Ge Göstergeleri Açısından Türkiye ve Gelişmiş Ülkelerle Kıyaslaması”, İşletme ve İktisat Çalışmaları Dergisi, 1(1), ss. 12-25. 
Ünal, Targan - Seçilmiş, Nisa (2014). "Satış Hasılatı Artışında Ar-Ge'nin Rolü ve Kârlılı̆̆ın Ar-Ge Harcamalarına Etkisi: Gaziantep Örneği”, Yönetim ve Ekonomi Araştırmaları Dergisi, 22, ss. 202-210.

Yaylalı, Muammer - Akan, Yusuf - Işık, Cem (2010). "Türkiye'de Ar\&Ge Yatırım Harcamaları ve Ekonomik Büyüme Arasındaki Eş-Bütünleşme ve Nedensellik İlişkisi:1990-2009”, Bilgi Ekonomisi ve Yönetim Dergisi, 5(2), ss. 13-26. 